Vol 10, Issue 12, 2017

\title{
A CLINICAL STUDY TO EVALUATE THE EFFICACY OF SAINDHAVADI TAILA MATRA VASTI IN THE MANAGEMENT OF AMAVATA W.S.R. RHEUMATOID ARTHRITIS
}

\author{
ARCHANA NEGI ${ }^{1 *}$, PUNITA PANDEY ${ }^{2}$, BHUPINDER SINGH ${ }^{1}$ \\ ${ }^{1}$ PG Department of Kayachikitsa, Rishikul Campus, Uttarakhand Ayurved University, Uttarakhand, India. ${ }^{2}$ Department of Kayachikitsa, \\ Gurukul Campus, Uttarakhand Ayurved University, Uttarakhand, India. Email: archananegi89@gmail.com
}

Received: 10 June 2017, Revised and Accepted: 15 August 2017

\section{ABSTRACT}

Objective: The objective of the study is to find the efficacy of Saindhavadi Taila Matra Vasti in the management of Amavata (rheumatoid arthritis [RA]).

Methods: For the present clinical study 15 patients of Amavata (RA) were registered from the Outpatient Department, PG Department of Kayachikitsa, Rishikul Campus, Haridwar. Saindhavadi Taila Matra Vasti was given $60 \mathrm{ml}$ once daily for 8 days, followed by an interval of 7 days. Again Vasti was given once daily for 8 days followed by gap of 7 days. Same cycle was repeated next month. Assessment of the patients was done on the basis of subjective, objective, and functional parameters at the interval of 15 days.

Results: Statistically significant result was found in subjective parameters such as pain intensity, Sandhishotha, Gaurav, Apaka (p<0.01 in each), Jwara, Aruchi, and Utsahahani ( $\mathrm{p}<0.05$ in each). Statistically non-significant result was found in all the functional parameters ( $\mathrm{p}>0.05$ ), that is, in grip strength, foot pressure, and goniometry. In biochemical parameters, statistically significant result was found in erythrocyte sedimentation rate only $(\mathrm{p}<0.05)$. Although non-significant result was found in other biochemical parameters such as hemoglobin, RA factor, and C-reactive protein (CRP) concentration, the mean scores of RA factor and CRP were reduced from $48.7 \mathrm{IU} / \mathrm{ml}$ and $10.4 \mathrm{mg} / \mathrm{L}$ before treatment to $25.8 \mathrm{IU} / \mathrm{ml}, 8.2 \mathrm{mg} / \mathrm{L}$ after treatment, respectively.

Conclusion: In the clinical study, patients got symptomatic relief in many of the complaints but no significant result was found in functional parameters and most of the biochemical parameters. Thus, it can be concluded that Saindhavadi Taila Matra Vasti alone is effective in mild-to-moderate cases of Amavata (RA) and in severe cases it can be used along with oral Ayurvedic formulations for better results.

Keywords: Amavata, Rheumatoid arthritis, Saindhavadi Taila Matra Vasti.

(C) 2017 The Authors. Published by Innovare Academic Sciences Pvt Ltd. This is an open access article under the CC BY license (http://creativecommons. org/licenses/by/4. 0/) DOI: http://dx.doi.org/10.22159/ajpcr.2017.v10i12.20647

\section{INTRODUCTION}

Amavata is one of the challenging joint diseases encountered by physicians in day-to-day practice due to its chronicity, progressive nature, complications, and morbidity. The term "Amavata" is derived from two words - "Ama" and "Vata" where the word Ama means improper or partially digested matter. When Ama and Vata Dosha are vitiated simultaneously and enters the Trika (pelvic girdle) and Sandhi (joints) leading to stiffness (Stabdhata) of the body, the condition is called Amavata [1]. Acharya Madhav has described causative factors for the disease as Viruddhahara (unwholesome diet), Viruddhachesta (erroneous habits), Mandagni, sedentary lifestyle, and exercising immediately after food [2]. Its symptoms include joint pain like that of scorpion bite, swelling, and stiffness in multiple joints with systemic features (Sarvadaihika Lakshanas) of Ama like Angamarda (myalgia), Aruchi (anorexia), Trishna (thirst), Alasya (laziness), Gaurav (heaviness), Jwara (pyrexia), Apaaka (indigestion), and Anga shunata (oedema). The clinical presentation of Amavata closely mimics with rheumatoid arthritis (RA), in accordance with their similarities in clinical features such as multiple joint pain, swelling, stiffness, fever, general debility. RA affects approximately $0.5-1 \%$ of the adult population worldwide [3]. The incidence of RA increases between 25 and 55 years of age, after which it plateaus until the age of 75 and then decreases [4]. Women are affected approximately 3 times more often than men [5].

Despite of various treatment measures available in allopathic system of medicine, the prevalence of the disease is quite high. Thus, it draws a major attention of the research scholars worldwide to work on the various aspects of this disease. The present study is aimed at finding the efficacy of Saindhavadi Taila Matra Vasti in the management of Amavata (RA).

Aims and objectives

1. To study the mode of action of Saindhavadi Taila Matra Vasti

2. To assess the efficacy of Saindhavadi Taila Matra Vasti on Amavata

\section{METHODS}

The study comprised of 15 patients of Amavata. The patients were selected from OPD and IPD of Rishikul campus, Haridwar.

\section{Selection of sample}

Randomized sampling

\section{Type of study}

Single blind.

\section{Duration of study}

60 days.

\section{Drug trial schedule}

Saindhavadi Taila Matra Vasti was given $60 \mathrm{ml}$ once daily for 8 days, followed by an interval of 7 days. Again Vasti was given once daily for 8 days followed by gap of 7 days. Same cycle was repeated next month.

\section{Assessment and follow-up}

The assessment of the patients was done at the interval of 15 days and the follow-up was done 1 month after completion of treatment. 
Inclusion criteria

- Patients having classical features of Amavata.

- Age group of 18-60 years

- Patients fulfilling American College of Rheumatology criteria, 1987.

- Both sero-positive and sero-negative cases were included in present study.

\section{Exclusion criteria}

- Chronicity for more than 15 years

- Having severe crippling deformity

- Patients with other systemic diseases such as cardiac disease, tuberculosis, diabetes mellitus, hypertension

- Any other serious medically and surgically ill patients.

\section{Criteria for assessment}

The assessment of the trial was done on the basis of following parameters:

1. Subjective

2. Objective

\section{Subjective}

The subjective assessment was done on the basis of:

Improvement in following signs and symptoms of Amavata as described in classics:

\begin{tabular}{ll}
\hline 1 & Sandhishoola (joint pain) \\
2 & Sandhishotha (joint swelling) \\
3 & Gaurav (heaviness in the body) \\
4 & Jwara (fever) \\
5 & Aruchi (loss of appeptite) \\
6 & Jaadya (morning stiffness) \\
7 & Sparshasahyata (tenderness) \\
8 & Apaaka (indigestion) \\
9 & Bahumutrata (frequency of micturition) \\
10 & Utsahahani (loss of vigor) \\
\hline
\end{tabular}

The above symptoms were graded as below:

None - 0

Mild - 1

Moderate - 2

Moderate to severe - 3

Severe - 4
Objective

The objective assessment was done on the basis of changes in relevant laboratory parameters and functional parameters.

\section{Biochemical parameters}

Hemoglobin $(\mathrm{Hb})$, total leukocyte count, differential leukocyte count, erythrocyte sedimentation rate (ESR), RA factor, and C-reactive protein (CRP).

Functional assessments

1. Grip strength

2. Foot pressure

3. Goniometry (range of motion)

\section{Statistical analysis}

Wilcoxon signed rank test was applied on the subjective and functional parameters. Paired t-test was applied on biochemical parameters. Thus, the obtained results were interpreted as:

$\mathrm{p}>0.05$ - not significant; $\mathrm{p}<0.01$ and $<0.05$ - significant; and $\mathrm{p}<0.001$ - highly significant.

\section{RESULTS AND DISCUSSION}

While observing subjective and objective assessment it was found that statistically significant results were found in subjective parameters such as pain intensity, Sandhishotha, Gaurav, Apaka ( $<<0.01$ in each), Jwara, Aruchi, and Utsahahani ( $\mathrm{p}<0.05$ in each). Statistically nonsignificant results were found in visual analog pain scale, pain frequency and duration, Jadya, Sparshasahyata, and Bahumutrata as value of ( $p>0.05$ ) in each. The percentage relief in all the subjective parameters is as follow: Visual analog pain scale $-7.3 \%$, pain intensity $-38.3 \%$, pain frequency - $26.0 \%$, pain duration - 25\%, Sandhishotha $-47.6 \%$, Gaurav - 58.8\%, Jwara - 83.3\%, Aruchi - 70.0\%, Jadya - 39.1\%, Sparshasahyata - 26.3\%, Apaka -64.7\%, Bahumutrata - 20\%, and Utsahahani - 27.3\% (Table 1).

Statistically non-significant results were found in all the functional parameters $(\mathrm{p}>0.05)$ (Table 2).

The percentage relief in functional parameters is as follow: Grip strength (right hand) - 15.4\%, grip strength (left hand) $-34.8 \%$, foot pressure (right hand) - 25\%, foot pressure (left hand) $-18.2 \%$, and goniometry - $22.3 \%$ (Table 2 )

In biochemical parameters, statistically significant result was found in ESR only $(\mathrm{p}<0.05)$. Mean ESR was reduced from $48.7 \mathrm{~mm} / \mathrm{h}$ before treatment to $35.7 \mathrm{~mm} / \mathrm{h}$ after treatment. The mean score of $\mathrm{Hb}$, RA

Table 1: Efficacy study of Matra Vasti on subjective parameters

\begin{tabular}{|c|c|c|c|c|c|c|}
\hline \multirow[t]{2}{*}{ Subjective parameters } & \multicolumn{2}{|c|}{ Median } & \multirow[t]{2}{*}{ Wilcoxon signed rank W } & \multirow[t]{2}{*}{ p value } & \multirow[t]{2}{*}{$\%$ Effect } & \multirow[t]{2}{*}{ Result } \\
\hline & BT & AT & & & & \\
\hline Visual analog pain scale & 3 & 3 & $-1.732^{\mathrm{a}}$ & $>0.05$ & 7.3 & Non-significant \\
\hline Pain intensity & 3 & 2 & $-3.080^{\mathrm{a}}$ & $<0.01$ & 38.3 & Significant \\
\hline Pain frequency & 3 & 3 & $-1.732^{\mathrm{a}}$ & $>0.05$ & 26.0 & Non-significant \\
\hline Pain duration & 3 & 3 & $-1.414^{\mathrm{a}}$ & $>0.05$ & 25.0 & Non-significant \\
\hline Sandhishotha & 1 & 1 & $-2.887^{\mathrm{a}}$ & $<0.01$ & 47.6 & Significant \\
\hline Gaurav & 1 & 0 & $-2.887^{\mathrm{a}}$ & $<0.01$ & 58.8 & Significant \\
\hline Jwara & 0 & 0 & $-2.236^{\mathrm{a}}$ & $<0.05$ & 83.3 & Significant \\
\hline Aruchi & 1 & 0 & $-2.121^{\mathrm{a}}$ & $<0.05$ & 70.0 & Significant \\
\hline Jadya & 2 & 2 & $-1.732^{\mathrm{a}}$ & $>0.05$ & 39.1 & Non-significant \\
\hline Sparshasahyata & 1 & 1 & $-1.000^{\mathrm{a}}$ & $>0.05$ & 26.3 & Non-significant \\
\hline Apaka & 1 & 0 & $-2.714^{\mathrm{a}}$ & $<0.01$ & 64.7 & Significant \\
\hline Bahumutrata & 0 & 0 & $-1.414^{\mathrm{a}}$ & $>0.05$ & 20.0 & Non-significant \\
\hline Utsahahani & 2 & 1 & $-2.449^{\mathrm{a}}$ & $<0.05$ & 27.3 & Significant \\
\hline
\end{tabular}


Table 2: Efficacy study of Matra Vasti on functional parameters

\begin{tabular}{|c|c|c|c|c|c|c|}
\hline \multirow[t]{2}{*}{ Functional parameters } & \multicolumn{2}{|c|}{ Mean } & \multirow[t]{2}{*}{ Wilcoxon signed rank W } & \multirow[t]{2}{*}{ p value } & \multirow[t]{2}{*}{$\%$ Effect } & \multirow[t]{2}{*}{ Result } \\
\hline & BT & AT & & & & \\
\hline Grip strength (right hand) & 1 & 1 & $-1.732^{\mathrm{a}}$ & $>0.05$ & 15.4 & Non-significant \\
\hline Foot pressure (right leg) & 0 & 0 & $-1.000^{\mathrm{a}}$ & $>0.05$ & 25.0 & Non-significant \\
\hline Foot pressure (left leg) & 0 & 0 & $-1.414^{\mathrm{a}}$ & $>0.05$ & 18.2 & Non-significant \\
\hline Goniometry & 2 & 2 & $-2.000^{\mathrm{a}}$ & $>0.05$ & 22.3 & Non-significant \\
\hline
\end{tabular}

$\mathrm{p}>0.05$ - not significant; $\mathrm{p}<0.01$ and $<0.05$ - significant; and $\mathrm{p}<0.001$ - highly significant

Table 3: Efficacy study of Matra Vasti on biochemical parameters

\begin{tabular}{|c|c|c|c|c|c|c|c|}
\hline Biochemical parameters & Mean & $\mathbf{N}$ & SD & SE & t value & $p$ value & Result \\
\hline \multicolumn{8}{|l|}{$\mathrm{Hb}$} \\
\hline BT & 10.7 & 12 & 0.85 & 0.22 & 1.625 & $>0.05$ & Non-significant \\
\hline AT & 10.4 & 12 & 0.74 & 0.19 & & & \\
\hline \multicolumn{8}{|l|}{ ESR } \\
\hline BT & 48.7 & 12 & 17.29 & 4.46 & 2.36 & $<0.05$ & Significant \\
\hline AT & 35.7 & 12 & 16.99 & 4.39 & & & \\
\hline \multicolumn{8}{|l|}{ RA factor } \\
\hline $\mathrm{AT}$ & 25.8 & 12 & 22.91 & 5.92 & & & \\
\hline \multicolumn{8}{|l|}{ CRP } \\
\hline BT & 10.4 & 12 & 16.45 & 4.25 & 1.067 & $>0.05$ & Non-significant \\
\hline AT & 8.2 & 12 & 10.28 & 2.65 & & & \\
\hline
\end{tabular}

ESR: Erythrocyte sedimentation rate, Hb: Hemoglobin, RA: Rheumatoid arthritis, CRP: C-reactive protein, SD: Standard deviation, SE: Standard error

Table 4: Estimation of overall response

\begin{tabular}{lll}
\hline \multirow{2}{*}{ Grading } & \multicolumn{2}{l}{ Overall response } \\
\cline { 2 - 3 } & Number of patients & \% Relief \\
\hline Excellent $(>75 \%)$ & 0 & 0 \\
Marked improvement $(50-74 \%)$ & 4 & 33.4 \\
Mild improvement $(25-49 \%)$ & 7 & 58.3 \\
No improvement $(<24 \%)$ & 1 & 8.3 \\
\hline
\end{tabular}

factor, and CRP was $10.7 \mathrm{~g} \%, 48.7 \mathrm{IU} / \mathrm{ml}$ and $10.4 \mathrm{mg} / \mathrm{L}$, respectively before treatment and after treatment it was reduced to $10.4 \mathrm{~g} \%$, $25.8 \mathrm{IU} / \mathrm{ml}, 8.2 \mathrm{mg} / \mathrm{L}$, respectively.

Probable mode of action of Saindhavadi Taila Matra Vasti

"Saindhavadi Taila" described in Bhaishajya Ratnawali in Amavata Chikitsa Adhyaya [6] was used for the purpose of Matra Vasti. Before understanding the mode of action of Saindhavadi Taila Matra Vasti it is important to know how Matra Vasti acts, how the drugs given through Vasti are absorbed.

Acharya Sushruta has given the following description about the mode of action of Vasti:

\section{“पक्वाशयाद् वस्तविर्यं खैर्देहमनुसर्पता "[7] \\ वृक्षमूले नषिक्तितानामपां वीर्यमवि द्रुमम् ॥ (Su. Chi. 35/25)}

This means Vasti given through rectum reaches the whole body just like water poured at the roots reach all the parts of the tree. Thus, according to Ayurveda, the Veerya (active principle) of the Vasti gets absorbed and then, through the general circulation reaches at the site of the lesion and relieves the disease.

Modern pharmacokinetic studies have also proved that drug administration through the rectum can achieve higher blood levels of the drug than administration through the oral route due to partial avoidance of hepatic first-pass metabolism (Fig. 1) [8].

Saindhavadi Taila has total 32 contents (Table 5).

Basically, it has Deepan-Pachan Dravyas such as Shunthi, Shatpushpa, Saindhav, Maricha, Ajmoda, Pippali, Pippali Mula. Thus, it causes AmaPachan. Most of its contents are Vata-Kaphahara such as Shatpushpa, Medaa, Kataphal, Kachoora, Chavya, Vidanga, Renuka-beeja, Nili Vriksha, Danti, Maricha, Ajmoda, Kushtha, Sarshap and Pippali, Vata and Kapha are the two main pathological factors in Amavata which get subsided by these contents. It also contains Vednasthapan and Shothahara dravyas such as Rasna, Erand Mula, Renuka Beeja, Nili Vriksha and Mulethi. Matra Vasti is a type of Sneha Vasti (Table 3). It causes nourishment and cures diseases caused by aggravated Vata. Acharya Chakradatta has also mentioned the use of Saindhavadi Taila Vasti in Amavata while describing its Chikitsa Sutra. Thus, it can be said Saindhavadi Taila Matra Vasti is effective in Amavata due to properties of its contents.

\section{CONCLUSION}

Amavata is a Kapha-Vata Pradhana Tridoshaja Vyadhi which has clinical features similar to RA. RA is an inflammatory disease of the joints, which is associated with activation and proliferation of immunomediated cells, such as T-cells, macrophages, neutrophils, and plasma cells [10]. Saindhavadi Taila Matra Vasti was effective in controlling symptoms such as pain intensity, Sandhishotha, Gaurav, Apaka, Jwara, Aruchi, and Utsahahani. In biochemical parameters, statistically significant result was found in ESR. Although non-significant result was found in other biochemical parameters such as Hb, RA factor, and CRP concentration but the mean scores of RA Factor and CRP were reduced from $48.7 \mathrm{IU} / \mathrm{ml}$ and $10.4 \mathrm{mg} / \mathrm{L}$ before treatment to $25.8 \mathrm{IU} / \mathrm{ml}, 8.2 \mathrm{mg} / \mathrm{L}$ after treatment, respectively. Thus, it can be concluded that mild-tomoderate symptomatic relief was found in the patients so, it can be said that Saindhavadi Taila Matra Vasti alone is effective in mild-tomoderate cases of Amavata (RA) and in severe cases, it can be used along with oral Ayurvedic formulations for better results. 

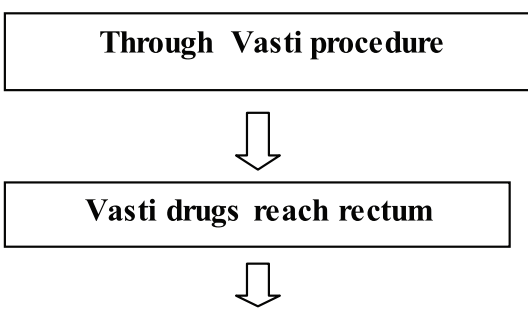

Rectal mucosa has rich blood \& lymph supply. Also rectal mucosa has lipid membrane

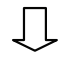

Thus, unionized and lipid soluble substances are readily absorbed from the rectum.

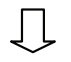

Drugs stimulate the neuroreceptors \& pressure receptors present in rectal wall

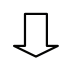

Results in inward rush of $\mathrm{Na}+$ ions \& generate action potential

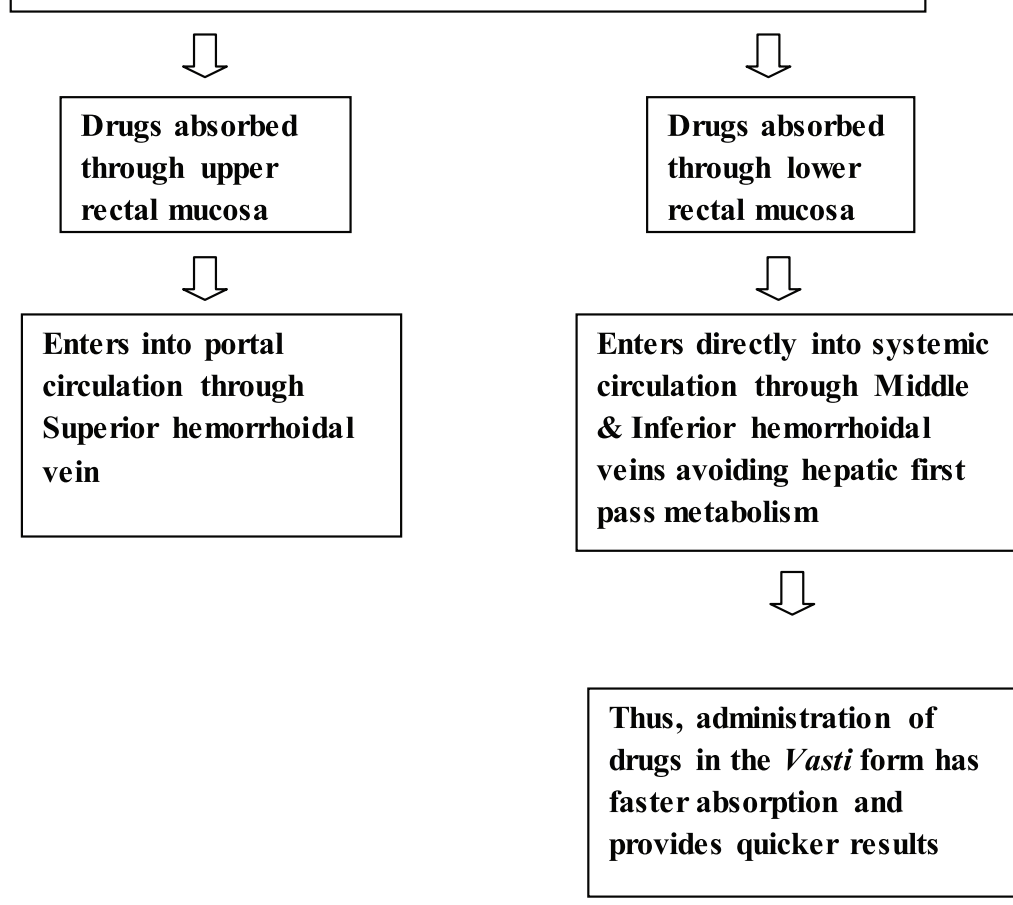

Fig. 1: Mode of action of Matra Vasti 
Table 5: Contents of Saindhavadi Taila [9]

\begin{tabular}{|c|c|c|c|c|c|c|c|}
\hline S.No. & Content & Latin name & Ratio & S.No. & Contents & Latin name & Ratio \\
\hline 1 & Saindhav lavan & Sodium chloride & 1 part & 17 & Kachoora & Curcuma zedoaria & 1 part \\
\hline 2 & Devadaru & Cedrus deodara & 1 part & 18 & Vayavidanga & Embelia ribes & 1 part \\
\hline 3 & Vacha & Acorus calamus & 1 part & 19 & Mulethi & Glycyrrhiza glabra & 1 part \\
\hline 4 & Shunthi & Zingiber officinale & 1 part & 20 & Renuka beeja & Vitex negundo seeds & 1 part \\
\hline 5 & Kataphala & Myrica esculenta & 1 part & 21 & Ateesa & Aconitum heterophyllum & 1 part \\
\hline 6 & Shatpushpa & Anethum sowa & 1 part & 22 & Erandamula & Ricinus communis & 1 part \\
\hline 7 & Nagarmotha & Cyperus rotundus & 1 part & 23 & Patha & Cissampelos pareira & 1 part \\
\hline 9 & Medaa & Polygonatum verticillatum & 1 part & 25 & Danti mula & Baliospermum montanum & 1 part \\
\hline 10 & Mahamedaa & Polygonatum cirrhifolium & 1 part & 26 & Maricha & Piper nigrum & 1 part \\
\hline 11 & Jayapala-beeja & Croton tinglium & 1 part & 27 & Ajmoda & Trachyspermum ammi & 1 part \\
\hline 12 & Nishotha & Operculina turpethum & 1 part & 28 & Pippali & Piper longum & 1 part \\
\hline 13 & Hijjal twaka & Barringtonia acutangula & 1 part & 29 & Kushtha & Sausurea lappa & 1 part \\
\hline 14 & Sugandhabala & Pavonia odorata & 1 part & 30 & Rasna & Pluchea lanceolata & 1 part \\
\hline 15 & Chitrakamula & Plumbago zeylanica & 1 part & 31 & Pippali mula & Piper longum & 1 part \\
\hline 16 & Bharangi & Clerodendrum serratum & 1 part & 32 & Sarshap Taila & Brassica campestris & 1 part \\
\hline
\end{tabular}

\section{REFERENCES}

1. Madhavakara, Nidan M. In: Upadhyaya Y, editor. Madhukosha Sanskrit Commentary by Sri Vijayraksita, Srikanthadatta and Hindi Commentary by Sri Sudarsana Sastri. Revised Edition. Varanasi: Chaukhambha Prakashana; 2008. p. 509.

2. Madhav, Vijayrakshit, Kanthdatta, Nidana M. In: Shasri S, editor. Amavata Nidana Adhyaya 25/1-2. Varanasi: Chaukhambha Prakashan; 2008. p. 508.

3. Longo DL, Fauci AS, Kasper DL, Hauser SL, Jameson JL, Loscalzo J, editors. Harrison's Principles of Internal Medicine. $18^{\text {th }}$ ed., Vol. 2. New York: The McGraw-Hill; 2012. p. 2738.

4. Madhavakara, Nidan M. In: Upadhyaya Y, editor. Madhukosha Sanskrit Commentary by Sri Vijayraksita, Srikanthadatta and Hindi Commentary by Sri Sudarsana Sastri. Amavata Nidana Adhyaya 25/7-10. Varanasi: Chaukhambha Prakashana; 2008. p. 511.

5. Shah SN, Anand MP, Acharya VN, Karnad DR, Bichile SK, Kamath SA, et al. API Textbook of Medicine. $7^{\text {th }}$ ed. Mumbai, India: Association of
Physician of India; 2003. p. 1160.

6. Sen GD. Bhaisajya Ratnawali with Hindi Commentary by Professor Siddhi Nandan Mishra. Amavata Chikitsa Adhyaya-29. Varanasi: Chaukhambha Subharti Prakashan; 1987. p. 612.

7. Samhita S. In: Shashtri AD, editor. Chikitsa Sthana 35/25 Nibandhasangraha Commentary of Shri Dalhanacharya. Varanasi: Chaukhambha Orientalia; 2010. p. 193

8. Khagra R, Mehta CS, Shukla VD, Dave AR. Clinical effect of Matra Basti and Vatari Guggulu in the management of Amavata (rheumatoid arthritis). AYU J 2010;31(3):343-50.

9. Acharya Priyavrata Sharma. Dravyaguna Vigyan-Part 2. $6^{\text {th }}$ ed. Varanasi: Chaukhambha Bharti Academy; 1982. p. 28, 39, 58, 66, 75, $126,152,253,275,294,300,331,335,355,362,370,389,403,420$, 426, 494, 503, 572,575, 627 .

10. Lad H, Dixit D, Joshi A, Bhatnagar D. Antioxidant and anti inflammatory effects of Vitex negundo on Freund's complete adjuvant induced arthritis. Int J Pharm Pharm Sci 2015;7(1):81-5. 